seek staff from abroad or with training overseas. And the administration is creating collaborations with overseas universities.

Furthermore, the new institutes put an emphasis on cutting-edge research, such as brain science at Monash and organometallic chemistry at UTAR. They send staff to international academic conferences and encourage publication in international journals.

"Right now the emphasis on research is not high," says Tham Choy-Yoong, dean of the faculty of science and engineering at UTAR. An astrophysicist formerly at the University of Cambridge's Cavendish

Laboratory, UK, Tham says he wants to introduce what he learned there. "In Britain, research is everything. It's more important than stressing how many students you can train."

A Malaysian developmental biologist who recently moved from a national university, and asked not to be named, says the independent institutes have a different philosophy. "The problem with the national universities is that there is too much central control, so the area of innovation is very limited. Universities should be a place to experiment."

\section{Cash flow}

That road will not be easy, as funding and human resources will continue to be a problem. The private universities only achieved the right to get grants from the main funding source, Intensification of Research in Priority Areas grants, two months ago. But even these have their problems, says Merilyn Liddell, vicechancellor of Monash Malaysia. She is particularly concerned that grants do not provide for major infrastructure or salary. "From the university's perspective, it costs money to get the grant," she says.

Moreover, the grants specify priority areas, focusing on applied science over basic research, says Liddell. Many researchers in Malaysia echo her concern, saying that R\&D investment seems focused on schemes to turn a quick profit rather than on long-term development. Much of the country's national research is on rubber, forestry and palm oil.

The grant system still causes concern, because the peer-review ideal is often replaced by patronage. "In Malaysia, the pool of people reading the grants is so small, they will clearly know who has written them," says Parhar. In a place where cronyism from the top down is rife, and ethnic lines clearly demarcated, the toll on merit-based assessment can be high.

This February, Monash Malaysia provided a report for the government advising it to put millions of dollars into basic-research activities at foreign-branch universities. "By training people in research, we could contribute to the human capital of the country," says Liddell.

The new universities are struggling to provide competitive salaries so that established scientists can be recruited to form a research core. One foreign scientist working in Malaysia says she couldn't even pay rent on her salary.

A shortage of colleagues and staff is also a lingering concern. There's a dire

Brain work: Ishwar Parhar intends to set up a centre of excellence in neuroscience.

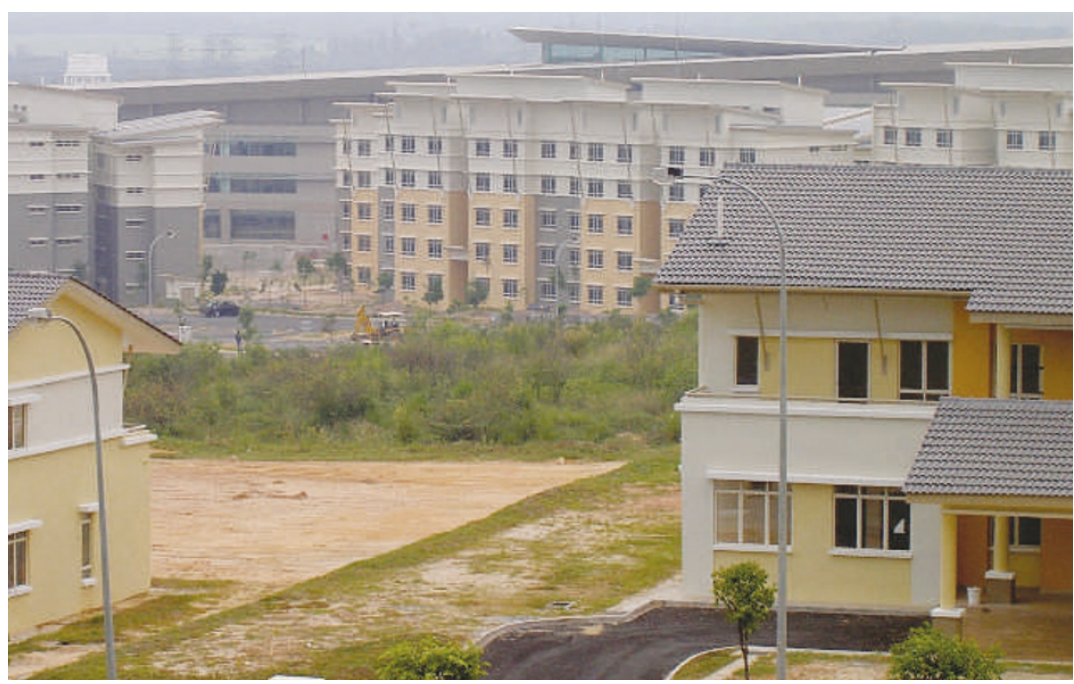

Taking the long view: the Asian Institute of Medicine, Science and Technology has ambitious expansion plans.

\section{WEB LINKS}

Universiti Tunku Abdul

Rahman

www.utar.edu.my

Monash University, Malaysia

www.monash.edu.my

Asian Institute of Medicine,

Science and Technology

www.aimst.edu.my

Penang Medical College

www.pmc.edu.my

International Medical

University

www.imu.edu.my

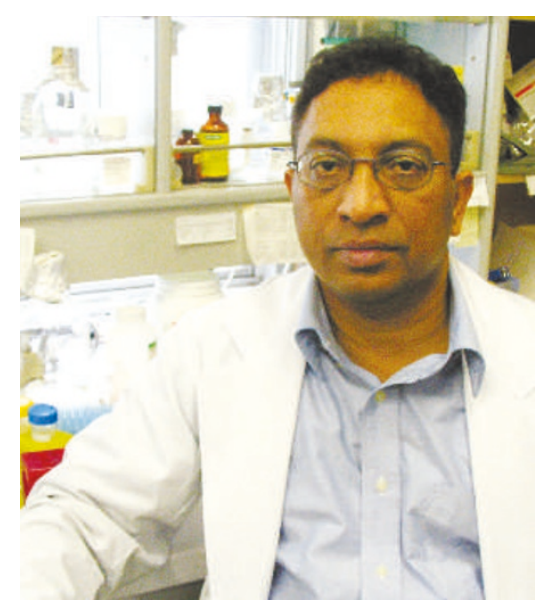

need for postgraduate students, says Das, "but Malaysian postdocs get only a small stipend, and foreigners get none". Parhar is bringing six of his own postdocs - four Japanese and two Chinese - to help set his institute up. But wholesale importing won't be an option for many.

Malaysia's famed biodiversity could be a great draw for researchers. But even that has been tainted by bad policies, say researchers. One foreign ecologist says that environmental-protection laws are not enforced, and considerable red tape must be hacked through before researchers can get out to the rainforests.

Meanwhile, the pool of scientists who could collaborate on biodiversity projects has shrunk. "Taxonomists are an endangered species," says Abdul Razak Mohd Ali, head of the Forest Research Institute of Malaysia, which is heading a national project on a biodiversity inventory. Many blame late-1990s policies designed to cultivate biotechnologists while supplanting taxonomists, but attitudes seem to be changing (see Nature 436, 313; 2005).

If the new institutes manage to attract top researchers, the Malaysian research community could develop basic and applied research capacity in line with international trends, as neighbouring Singapore has done (see Nature 425, 746-747; 2003).

Parhar is hopeful. He plans, among other things, to establish an active neuroscience and endocrinology society that could host the International Brain Research Organization's annual meeting.

"I want this to become a regional centre of excellence in neuroscience," says Parhar. "Once we show good-quality research, we will become attractive to scientists in the region and even to some in the United States and Europe."

David Cyranoski is Nature's Asia-Pacific correspondent.

\section{Correction}

A story in Naturejobs about England's Golden Triangle (Nature 436, 144-147; 2005) stated incorrectly that Millennium Pharmaceuticals left Cambridge after six weeks. Millennium had a presence in Cambridge during 2000-03, but decided to leave the country six weeks after moving into a new facility at Cambridge's Granta Park. The story also incorrectly said that no Cambridge area firm floated on the stock market in 2004. Millennium spin-out Sareum went public in October 2004, floating on the AIM market on the London Stock Exchange. Naturejobs regrets the errors. 